\title{
Transformative networks and public
participation in local government in the \\ Transformative networks and public
participation in local government in the post-COVID era
}

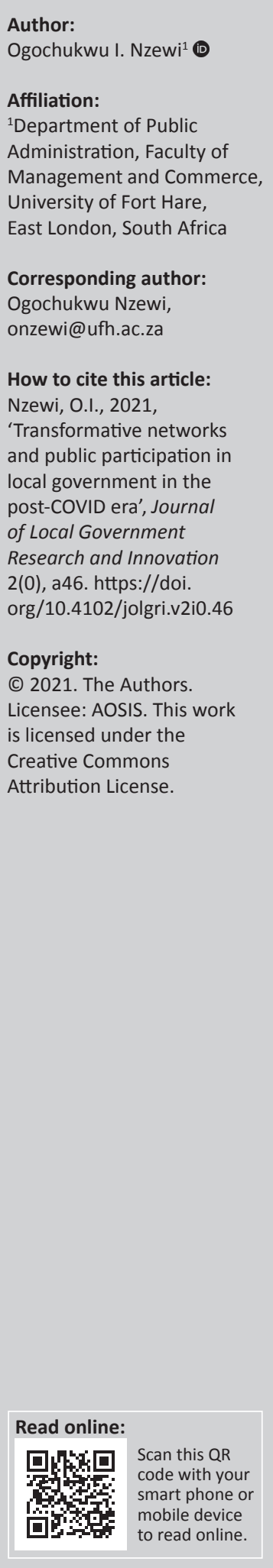

Power to the people! This is a mantra a lot of us are familiar with. It is also a mantra that is largely associated with the search for democratic values and the struggle for a more equal society. However, realising power to the people even in a democracy is one of the most complicated endeavours for government in general and local government in particular.

The past 2 years represents substantial changes in global governance because of the impact of the coronavirus disease pandemic. The world experienced and is still grappling with a clear and present danger, which shut down the world for months. The coronavirus disease (COVID-19) shifted the global order as we know it. In January 2020, at the time of writing the editorial of our last issue, there was no forecasting of the catastrophe that was about to be unleashed into the world. In hindsight however, the editorial entitled Re-envisioning local government studies, research and practice for the future, seemed to have foretold the impending global shut down, which not only imposed real time changes in the way we lived and worked but initiated the re-envisioning of the way government works.

The COVID-19 outbreak, did not only present a perfect storm to test both the economic and health disaster management apparatus of governments globally. Indeed, the virus presented human living contradictions in the sense that the virus compelled social distancing, which some can argue that it posed an existential threat to the lifeblood of 'people' as social animals. Critical to this JOLGRI issue is how the pandemic upended human interaction and relationships: a core component of our existence on planet earth.

On the one hand, interpersonal relationships, congregational interactions, government to people, people to government and government to government engagement became uncertain, disjointed and uninspiring. In particular for local government practice, the pandemic amplified the disjuncture in those participatory and human networking spaces. However, on the other hand, the pandemic created a hard reckoning with public participation towards mitigating the threats it posed.

Munzhedzi and Phago (2020) highlighted how COVID-19 amplified the dysfunction in local government in South Africa, from capacity and skill deficits to the transformative stagnation of rural municipalities. The authors proposed a human centred approach to tunnel through the post-COVID-19 aggravated dysfunction. It is perhaps fitting that for good governance to thrive after a pandemic that threatened human interaction, a human centred approach will be germane.

In an examination of three community approaches to threats of COVID-19 in Oman, Al Siyabi et al. (2020), showed how existing community participation strategies in primary healthcare (PHC) were adapted to run communication and quarantine programmes in the local community and with vulnerable groups such as migrant communities. Their research showed that community networks and a bottom up or grassroots approach create a sense of banding together, which is needed to provide context-specific interventions to tackle the immediate challenges of disruptive crisis.

In another study, Lovari, D'Ambrosi and Bowen (2020) showed how the pandemic created a deterministic shift in strategies previously considered ideal in government/citizen interactions. The study showed how quickly distrust builds between citizens and government in the time of crisis and proposed an ethical dimension to government communication strategies to minimise those risks. 
These studies show a hard shift in previously designed public participatory strategies as the world scrambled to deal with the coronavirus health crisis. It is thus not surprising that this year, the articles that have gone through our processes have a strong people's focus.

So how did COVID-19 magnify old participatory governance challenges and what new ways can local governments find to solve old challenges? This issue presents some answers to these two questions.

In this issue, the journal articles explore innovation in participatory spaces. Firstly, by examining multiple dimensions of public participation. Articles from South Africa in particular provide a sharp focus on new ways of viewing existing public participation spaces and engagements. For instance, the article on participative Integrated Development Planning praxis in local government provides a rational appraisal of the requirements for Integrated Development Planning and public participation measures thereof. The article inspires sincere questions on whether these requirements are not overtly ambitious, especially for the least resourced and rural local municipalities. Using a wide scope of 11 urban and rural municipalities, the article interrogates the implementation of legislated Integrated Development Plan (IDP) processes and finds that approaches to how municipalities implement participatory IDP processes must be creative, targeted and adaptive to unique contexts of local government given the severe spatial differentiation of the rural and urban representation of municipalities in South Africa.

Secondly, and particularly to citizens themselves, articles in this issue push for a re-imagining of citizens participation by literally adopting the concept of 'power to the people': in other words identifying 'power' as the missing link in citizens' experience of participation. These articles stimulate deeper interrogation of citizens' protest and disgruntlement over services. For instance, could it be that in search for ownership (through the power of decision making), citizens resort to violent protest to impose that sense of "voice' and power missing in those participatory spaces?

In line with the running theme of networks and 'social interactions' of this issue, another submission focuses on the government networks needed for adaptation and innovation in local government service delivery. The submission examines the often under researched area of twinning in local government practice. Even more interesting is the focus on twinning between African cities, which is even less explored in literature. The original research examines how the network between Bulawayo and eThekwini local government twinning arrangement has impacted improved service delivery for the city of Bulawayo in Zimbabwe. This alternative service delivery model not only promotes the concept of African self-sufficiency but also shows how under resourced municipalities can leverage easier accessible local resources and creative ideas to improved services for local citizens.

In this issue, we also publish two articles under our COVID-19 special collection. These articles show how COVID-19 illuminated government/citizens' distrust and re-enforced distrust between groups in society: Firstly, in Nigeria where state security forces resorted to violence and intimidation in 'enforcing' the lockdown measures and monitoring the distribution of COVID-19 palliatives. Secondly, in South Africa, where distrust between citizens and migrants was magnified during the December exodus of foreign nationals through the Beitbridge border post to their home countries. This was after a long hiatus caused by many months of restrictive lockdown.

The recommendations from these articles provide new insight into how local government can re-strategise in building public participatory spaces and trust postCOVID-19. For instance, these articles show how local government becomes the first 'responder' in these times of crisis, whether it is in terms of providing humanitarian relief needed at the Beitbridge border post or working with Community Organisations such as Faith Based Organisations to monitor and mitigate the excessive use of force by state security agents.

Finally, given the challenges of various governments with the vaccination of citizens against COVID-19 and its variants across the globe, it is clear that going into the future we will continue to grapple with the fall out of COVID-19. It is our expectation that this particular issue provides our readers with important context-based research information. Furthermore, we hope that this issue inspires our future research and practice so that communities continue to search for better ways to build on our common humanity and grow the space for dialogue, engagement and partnership at the local government level.

\section{References}

Al Siyabi, H., Al Mukhaini, S., Kanaan, M., Al Hatmi, S., Al Anqoudi, Z., Al Kalbani, A. et al., 2020, 'Community participation during COVID-19 pandemic', Frontiers in Public Health 8, 1044. https://doi.org/10.3389/fpubh.2020.616763

Lovari, A., D'Ambrosi, L., \& Bowen, S.A., 2020, 'Re-connecting voices. The (new) strategic role of public sector communication after the Covid-19 crisis', Partecipazione e Conflitto 13(2), 970-989.

Munzhedzi, P.H. \& Phago, K., 2020, 'Necessitating a Germane developmental local government agenda in South Africa: A post COVID-19 contemplation', African Journal of Governance \& Development 9(1.1), 181-199. 